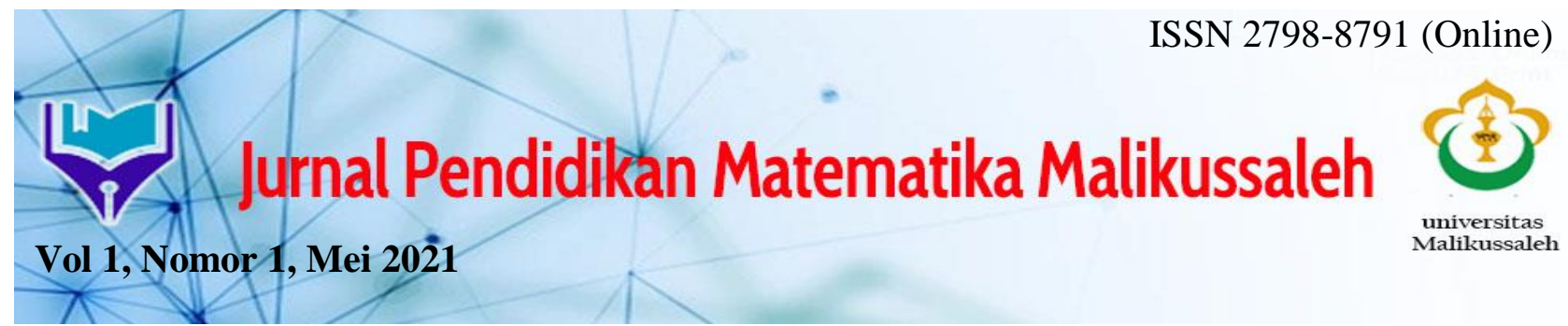

\title{
PENGARUH MODEL PEMBELAJARAN THINK PAIR SHARE TERHADAP PENINGKATAN KEMAMPUAN PEMECAHAN MASALAH MATEMATIS SISWA
}

\author{
Muhammad Sabiq ${ }^{1)}$, Marhami ${ }^{2) *}$ Muliana ${ }^{3)}$ \\ ${ }^{1,2,3}$ Program Studi Pendidikan Matematika, Universitas Malikussaleh, Aceh Utara, Indonesia \\ "Email: marhami@unimal.ac.id
}

\begin{abstract}
Abstrak
Penelitian ini bertujuan untuk melihat peningkatan kemampuan pemecahan masalah matematis siswa yang memperoleh model pembelajaran Think Pair Share (TPS) lebih baik daripada siswa yang memperoleh pendekatan pembelajaran scientific. Penelitian ini merupakan penelitian quasi eksperimen dengan desain Non-equivalen Control Group Design. Populasi yang diambil pada penelitian ini adalah siswa kelas X SMK Negeri 7 Lhokseumawe dan sampel terdiri atas kelas eksperimen dan kelas kontrol. Pengambilan data pada penelitian ini menggunakan intrumen tes dan non tes (angket respon siswa). Hasil analisis data menunjukkan bahwa hasil skor rataan $\mathrm{N}$ Gain pada kelas eksperimen yang menerapkan Model TPS 0,82 (Tinggi) lebih tinggi dari pada rataan $N$-Gain pada kelas kontrol yang menerapkan pendekatan scientific 0,77 (Tinggi). Berdasarkan hasil uji Indenpendent sampel $t$ Test sampel posttest didapatkan 0,471 yang dimana sig $\geq 0,05 \quad H_{o}$ diterima artinya tidak terdapat pengaruh kemampuan pemecahan masalah matematis siswa yang diajarkan dengan model TPS dengan kemampuan pemecahan masalah yang diajarkan dengan pembelajaran scientific. Analisis data uji t $N$-Gain menggunakan uji Indenpendent sampel $t$ Test dengan hasil 0,224 yang dimana sig $\geq 0,05$ yang artinya peningkatan kemampuan pemecahan masalah matematis siswa yang diajarkan dengan model TPS sama secara signifkan dengan kemampuan pemecahan masalah yang diajarkan dengan pembelajaran scientific.
\end{abstract}

Kata Kunci: Kemampuan Pemecahan Masalah Matematis Siswa, Think Pair Share (TPS), Pendekatan Scientific.

\section{PENDAHULUAN}

Matematika merupakan salah satu ilmu yang sangat besar peranannya terhadap ilmu pengetahuan dan teknologi, sehingga matematika perlu dipahami baik-baik. Menurut (Latif, 2017) matematika adalah salah satu bidang studi yang diajarkan di segala jenjang pendidikan, mulai dari sekolah dasar (SD) sampai pada jenjang perguruan tinggi. Matematika memegang peranan penting dalam menciptakan sumber daya manusia (SDM) yang berkualitas, sebab dalam matematika terkandung berbagai konsep yang logis dan realistis yang mampu membentuk pola pikir manusia dalam pengembangan ilmu pengetahuan dan teknologi. Menurut (Aditya, 2018) matematika merupakan ilmu pasti yang di pelajari mengenai pola pikir pembuktian secara logika pola mengorganisasikan dan beberapa konsep mengenai bilangan yang mempunyai hubungan 


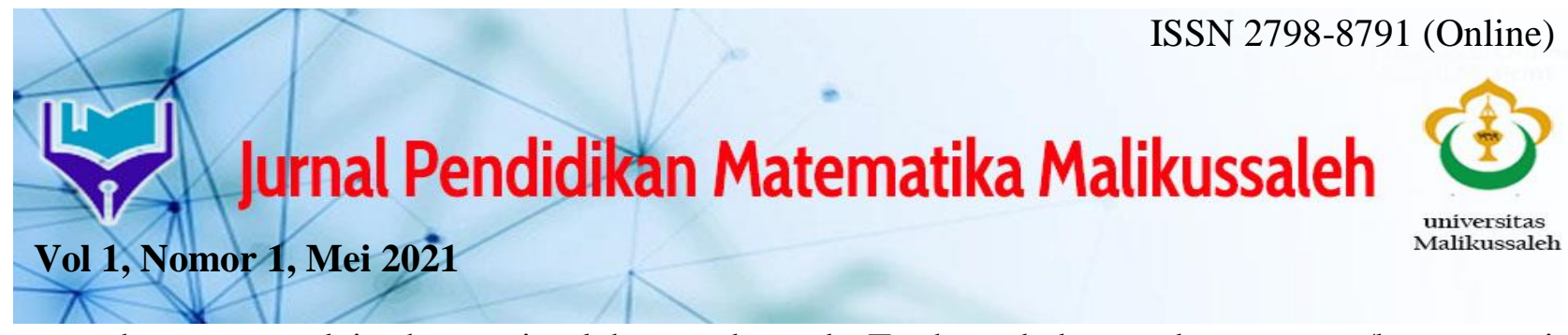

satu dengan yang lain dengan jumlah yang banyak. Terdapat beberapa kemampuan/kompetensi dalam matematika, salah satunya kemampuan pemecahan masalah matematis.

Kemampuan pemecahan masalah matematis siswa merupakan salah satu kemampuan yang harus dimiliki siswa dalam memecahkan suatu permasalahan baik dalam bidang ilmu matematika maupun dalam bidang ilmu yang lainnya. Pemecahan masalah merupakan proses menghubungkan informasi sebelumnya dengan informasi yang baru sehingga dapat mengatasi kesulitan dalam menyelesaikan solusi-solusi matematika

Namun kenyataannya dilapangan sering ditemukan bahwa kemampuan pemecahan masalah siswa cenderung masih rendah. Rendahnya kemampuan pemecahan masalah matematis siswa di Indonesia juga dapat dilihat dari hasil survei PISA (Program for International Student Assesment ) tahun 2009 yang menunjukkan bahwa Indonesia menempati peringkat ke- 61 dari 65 negara yang di survei dengan nilai rata - rata kemampuan pemecahan masalah matematis siswa di Indonesia 371 dari nilai rata - rata yang ditetapkan PISA adalah 500 (Afriansyah dan Ulvah, 2016). Adapula penelitian yang dilakukan (Hendri, Sherlyane; Kenedi, 2018) rendahnya kemampuan pemecahan masalah siswa juga terlihat pada hasil ulangan harian siswa kelas VIII SMPN 15 Padang. Hal ini disebabkan karena siswa tidak dilibatkan secara langsung dalam penemuan konsep sehingga siswa cenderung menghafal rumus tanpa memahami konsep, akibatnya siswa cenderung tidak mampu dalam memecahkan masalah.

Menurut (Fatimah, 2016) rendahnya kemampuan pemecahan masalah matematis siswa dikarenakan kegiatan pembelajaran yang masih berpusat pada guru dan penggunaan pendekatan pembelajaran yang masih kurang relevan. Bisa dikatakan penyebab malasnya siswa belajar karena banyaknya masih guru yang mengajar yang menggunakan metode atau pendekatan tradisional dan cenderung monoton membuat bosan siswa dalam mengikuti proses belajar mengajar. Guru cenderung menerapkan pendekatan yang dimana pendekatan tersebut memerlukan waktu yang cukup lama untuk guru menjelaskan di depan, dan guru tidak dapat membuat sebuah inovasi dalam mengajar sehingga murid cenderung menjadi bosan dan malas untuk mengikuti pembelajaran berlangsung.

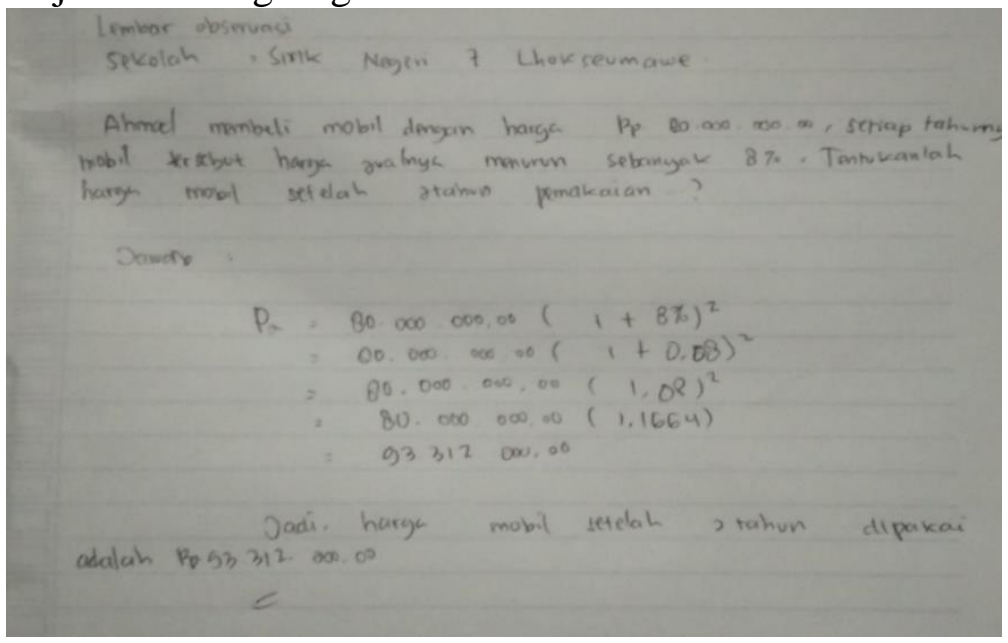

Gambar 1. Lembar Observasi Jawaban siswa 


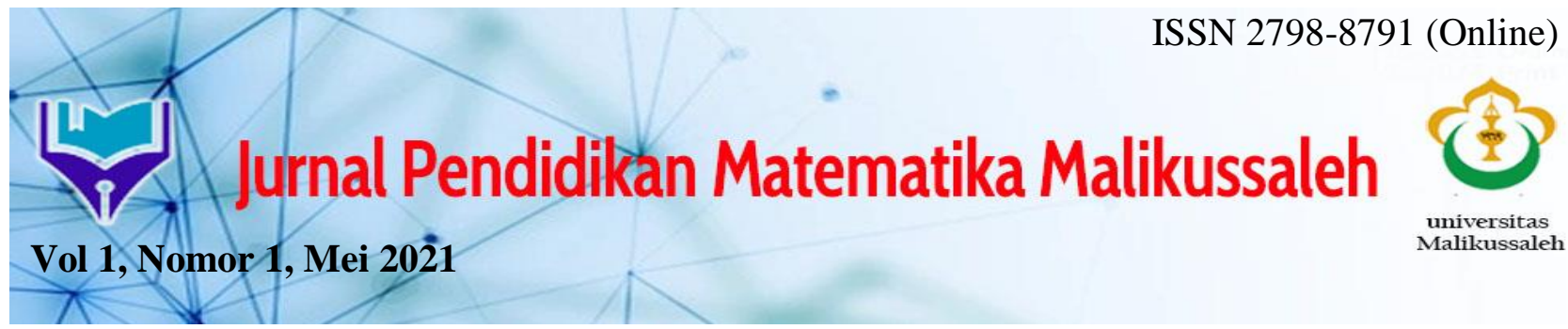

Dari penyelesaian soal di atas dapat dilihat bahwa siswa banyak salah dalam menyelesaikan soal yang diberikan. Jawaban diatas dapat dilihat siswa kurang bisa memahami masalah matematika yang diberikan siswa kurang bisa membuat apa yang diketahuhi dan apa yang ditanyakan. SMK Negeri 7 Lhokseumawe di kelas XI terdapat 23 siswa yang dimana dalam penyelesaiannya terdapat beberapa jawaban-jawaban yang bervariasi yang dimana terdapat 6 siswa yang menjawab soal tersebut salah dalam membuat yang diketahui dan apa yang ditanyakan dan ada juga yang tidak bisa membuat apa yang diketahui dan ditanyakan, terdapat 10 siswa yang tidak bisa membuat model matematika untuk menyelesaikan soal tersebut, dan ada juga 3 siswa yang bisa yang bisa menyelesaikan soal tersebut mampu membuat apa yang diketahui dan ditanyakan dan bisa membuat pemodelan matematikanya akan tetapi siswa tersebut tidak membuat kesimpulan dari soal tersebut. Oleh karena itu dapat dikatakan bahwa kemampuan pemecahan masalah matematis siswa di SMK Negeri 7 Lhokseumawe masih sangat rendah.

Berdasarkan permasalahan diatas digunakan salah satu model pembelajaran yang dapat meningkatkan kemampuan pemecahan masalah matematis siswa yaitu model pembelajaran Think Pair Share (TPS). Model pembelajaran Think Pair Share (TPS) merupakan suatu model pembelajaran yang kooperatif yang berguna untuk mempengaruhi pola interaksi para siswa dan memberikan banyak ruang untuk siswa lebih banyak berfikir, dan saling membantu menyelesaikan masalah. Menurut (Sani \& Kurniasih, 2016) model pembelajaran Think Pair Share menggunakan metode diskusi berpasangan yang dilanjutkan dengan diskusi pleno. Dengan model ini siswa dilatih bagaimana mengutarakan pendapat dan siswa juga belajar meghargai pendapat orang lain dengan tetap mengacu pada materi atau tujuan pembelajaran (Marhami, 2018). Ada beberapa penelitian yang menyatakan bahwa model Think Pair Share dapat meningkatkan minat belajar siswa dan meningkatkan kemampuan siswa. Penelitian yang dilakukan oleh (Zulfah, 2017) berdasarkan hasil perhitungan tes kemampuan pemecahan masalah matematis siswa pada materi lingkaran diperoleh rata-rata kemampuan pemecahan masalah matematis siswa yang menerapkan model pembelajaran kooperatif tipe Think Pair Share dengan pendekatan Heuristik adalah 65,9 lebih tinggi dari pada rata-rata kemampuan pemecahan masalah siswa yang menerapkan pembelajaran konvensional yaitu 51,1, maka perlakuan (treatment) yang diberikan pada kelompok eksperimen berpengaruh positif. Selanjutnya penelitian yang dilakukan (Witaningtyas et al., 2016), hasil penelitian menunjukkan bahwa terdapat perbedaan hasil belajar antara siswa yang dibelajarakan dengan model pembelajaran kooperatif tipe Think Pair Share (TPS) dengan siswa yang dibelajarkan dengan pembelajaran secara konvensional.

Berdasarkan latar belakang diatas, maka tujuan dari penelitian ini adalah: (1) Untuk melihat pengaruh kemampuan pemecahan matematis siswa kelas X SMK Negeri 7 Lhokseumawe setelah dilakukannya pembelajaran matematika dengan menggunakan model pembelajaran kooperatif tipe Think Pair Share (TPS) dalam meningkatkan kemampuan pemecahan masalah matematis siswa; dan (2) Untuk mengetahui peningkatan kemampuan pemecahan masalah matematis siswa yang diberikan model Think Pair Share (TPS) dan pembelajaran biasa di kelas X SMK Negeri 7 Lhokseumawe. 


\section{METODE}

\section{Jenis Penelitian}

Penelitian ini menggunakan pendekatan kuantitatif. Jenis penelitian yang digunakan pada penelitian kali ini adalah quasi eksperimen. Menurut (Sugiyono, 2016) quasi eksperimen mempunyai kelompok kontrol, tetapi tidak dapat berfungsi sepenuhnya untuk mengontrol variabel - variabel luar yang mempengaruhi pelaksanaan eksperimen.

\section{Waktu dan Tempat Penelitian}

Tempat penelitian ini dilakukan di SMK Negeri 7 Lhokseumawe di kelas X, pada semester genap tahun ajaran 2019 / 2020.

\section{Populasi dan Sampel Penelitian}

Populasi yang dipilih dalam kesempatan kali ini adalah semua peserta didik yang terdapat di kelas X pada SMK Negeri 7 Lhokseumawe tahun ajaran 2019 / 2020. Teknik penentuan sampel menggunakan purposive sampling dimana sampel dipilih berdasarkan tujuan tertentu. Pemilihan sampel pada penelitian ini didasarkan pada hasil diskusi dari guru mata pelajaran matematika. Dengan demikian sampel yang diambil sebanyak dua kelas yaitu kelas $\mathrm{X}$ mesin (kelas eksperimen) berjumlah 19 siswa dan kelas X kimia (kelas kontrol) berjumlah 17 siswa yang dimana masing-masing kelas memiliki kemampuan akademik setara berdasarkan pertimbangan dari guru bidang studi matematika.

\section{Prosedur Penelitian}

Desain penelitian yang digunakan yaitu Quasi Eksperimenal Design. Dimana bentuk design yang digunakan yaitu Non-equivalen Control Group Design, dimana desain ini hampir sama dengan pretest-posttest control group design, hanya saja pada design ini kelompok eksperimen maupun kelompok kontrol tidak dipilih secara random (Sugiyono, 2016).

Tabel 1. Desain Penelitian

\begin{tabular}{|l|c|c|c|}
\hline Think Pair Share (TPS) & $O_{1}$ & $\mathrm{X}$ & $O_{2}$ \\
\hline Scientific & $O_{1}$ & - & $O_{2}$ \\
\hline
\end{tabular}

$$
\text { Modifikasi dari (Sugiyono, 2016) }
$$

Keterangan:

$O_{1}=$ Pre-test

$\mathrm{O}_{2}=$ Post-test

$\mathrm{X}=$ Diberikan perlakuan berbentuk model pembelajaran TPS

\section{Data, Intrumen, dan Teknik Pengumpulan Data}

Data dikumpulkan melalui hasil ujian (tes), tes dilakukan dua kali dengan tes awal (pretest) dan tes akhir (posttest). indikator pemecahan masalah matematis siswa yang digunakan dalam penelitian ini adalah sebagai berikut (Handayani, 2017) : 


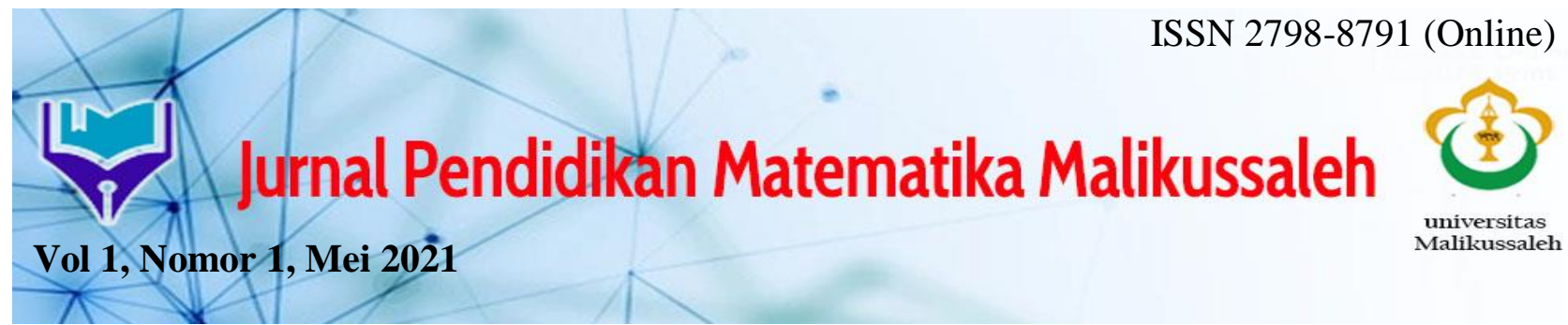

1. Menunjukkan pemahaman masalah, meliputi kemampuan mengidentifikasi unsur-unsur yang diketahui, ditanyakan, dan kecukupan unsur yang diperlukan.

2. Mampu membuat atau menyusun model matematika, meliputi kemampuan merumuskan masalah situasi sehari-hari dalam matematika

3. Memilih dan mengembangkan strategi pemecahan masalah, meliputi kemampuan memunculkan berbagai kemungkinan atau alternatif cara penyelesaian rumus-rumus atau pengetahuan mana yang dapat digunakan dalam pemecahan masalah tersebut.

4. Mampu menjelaskan dan memeriksa kebenaran jawaban yang diperoleh, meliputi kemampuan mengidentifikasi kesalahan-kesalahan perhitungan, kesalahan peggunaan rumus, memeriksa kecocokan antara yang telah ditemukan dengan apa yang ditanyakan dan dapat menjelaskan kebenaran jawaban tersebut.

\section{Teknik Analisis Data}

Teknik analisis data yang digunakan pada penelitian ini dilakukan dengan uji syarat statistik yaitu uji hipotesis dengan menggunakan uji-t dengan syarat uji normalitas dan uji homogenitas. Seluruh perhitungan statistik menggunakan sofware SPSS 25.

\section{HASIL DAN PEMBAHASAN}

Pada penelitian ini memiliki 2 hipotesis yaitu untuk melihat pengaruh (posttest) dan untuk melihat peningkatan ( $N$-Gain) siswa terhadap model Think Pair Share. Data - data tersebut akan dilakukan uji statistic untuk menguji hipotesis tersebut.

Uji normalitas bertujuan untuk melihat data yang didapatkan berdistribusi normal atau tidak. Uji normalitas yang digunakan adalah dengan uji Kolmogorov-Smirnov secara operasional hipotesis di atas dirumuskan:

$H_{0}=$ Data berasal dari populasi yang berdistribusi normal

$H_{a}=$ Data berasal dari populasi yang berdistribusi tidak normal

Dengan kriteria pengujian:

Jika nilai Sig. (p-value) $<\alpha(\alpha=0,05)$, maka $H_{0}$ ditolak

Jika nilai Sig. ( $p$-value $) \geq \alpha(\alpha=0,05)$, maka $H_{0}$ diterima

Tabel 2. Hasil Uji Normalitas Data Posttest

\begin{tabular}{ccccc}
\hline \multirow{2}{*}{ Kelas } & \multicolumn{3}{c}{ Kolmogorov-Smirnov } & \multirow{2}{*}{ Kesimpulan } \\
\cline { 2 - 4 } & Statistic & Df & Sig & \\
\cline { 1 - 4 } Eksperimen & 0,128 & 19 & 0,200 & $H_{o}$ diterima \\
\cline { 1 - 4 } Kontrol & 0,206 & 17 & 0,053 & \\
\hline
\end{tabular}

Hasil uji normalitas skor posttest kemampuan pemecahan masalah matematis siswa yang dihitung menggunakan uji Kolmogorov-Smirnov terlihat bahwa skor posttest kemampuan pemecahan masalah matematis siswa di kelas eksperimen dan kelas kontrol memiliki nilai sig $>\alpha=0,05$ dikatakan $H_{o}$ diterima. Hasil uji normalitas skor $\mathrm{N}$-Gain kemampuan pemecahan masalah matematis siswa pada kelas eksperimen dan kelas kontrol dikatakan berdistribusi normal. 


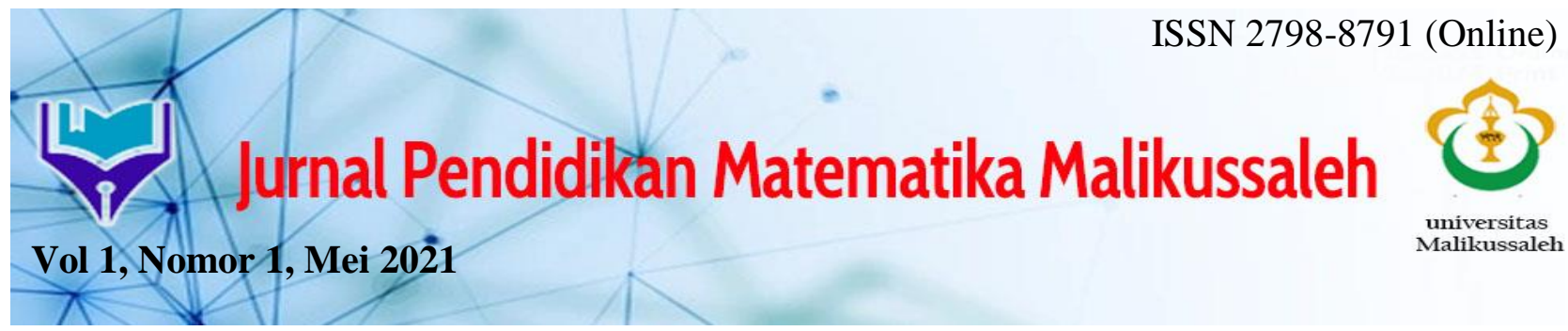

Uji homogenitas dilakukan untuk melihat variasi data bersifat homogen atau tidak.Sebelumnya, hasil uji normalitas di kelas eksperimen dan kelas kontrol berdistribusi normal, selanjutnya akan di lakukan uji homogenitas. Uji homogenitas dilakukan dengan menggunakan uji levence.

Adapun prosedurnya menggunakan Uji Homogenety Variance (Levence Statistic) antara lain :

$\mathrm{H}_{0}: \sigma_{1}=\sigma_{2}$, kedua sampel berasal dari populasi yang memilikivarians yang homogen.

$\mathrm{H}_{\mathrm{a}}: \sigma_{1} \neq \sigma_{2}$, kedua sampel berasal dari populasi yang memiliki varians yang tidak homogen.

Dengan $\sigma_{1}=$ Varians data kelompok eksperimen

$\sigma_{2}=$ Varians data kelompok kontrol

Jika nilai Sig. $(p$-value $)<\alpha(\alpha=0,05)$, maka $H_{0}$ ditolak

Jika nilai Sig. (p-value) $\geq \alpha(\alpha=0,05)$, maka $H_{o}$ diterima

Tabel 3. Hasil Uji Homogenitas Data Skor Posttest

\begin{tabular}{lllll} 
Based On Mean & Levene Statistic & df1 & df2 & Sig \\
\cline { 2 - 5 } & 0,039 & 1 & 34 & 0,845
\end{tabular}

Hasil uji homogenitas data $\mathrm{n}$-gain kemampuan pemecahan masalah matematis siswa pada kelas eksperimen dan kelas kontrol adalah 0,845 dinyatakan bahwa nilai $p$ value sig $\geq 0,05 H_{a}$ diterima, sehingga dapat dikatakan bahwa uji homogenitas data posttest kemampuan pemecahan masalah matematis siswa pada kelas eksperimen dan kelas kontrol adalah homogen.

Uji t rata-rata posttestdi dalam penelitian ini menggunakan uji indenpendent sampel $t$ testbertujuan untuk melihat kemampuan pemecahan masalah matematis siswa yang memperoleh pembelajaran Think Pair Share (TPS) terdapat pengaruh secara signifikan dengan pembelajaran pendekatan scientific. Untuk menguji hipotesis penelitian yang diajukan diatas, dapat dirumuskan hipotesis statistiknya sebagai berikut:

$H_{0}: \mu_{1}=\mu_{2}$ : Tidak terdapat pengaruh secara signifikan pada penyajian kemampuan pemecahan masalah matematis siswa yang diajarkan dengan model pembelajaran Think Pair Share (TPS) dengan kemampuan pemecahan masalah matematis siswa yang diajarkan dengan pembelajaran scientific.

$H_{a}: \mu_{1} \neq \mu_{2}$ : Terdapat pengaruh secara signifikan pada penyajian kemampuan pemecahan masalah matematis siswa yang diajarkan dengan model pembelajaran Think Pair Share (TPS) dari kemampuan pemecahan masalah matematis siswa yang diajarkan dengan pembelajaran scientific.

Dengan kriteria pengujian :

Jika nilai Sig. (p-value) $<\alpha(\alpha=0,05)$, maka $H_{0}$ ditolak

Jika nilai Sig. (p-value) $\geq \alpha(\alpha=0,05)$, maka $H_{0}$ diterima. 


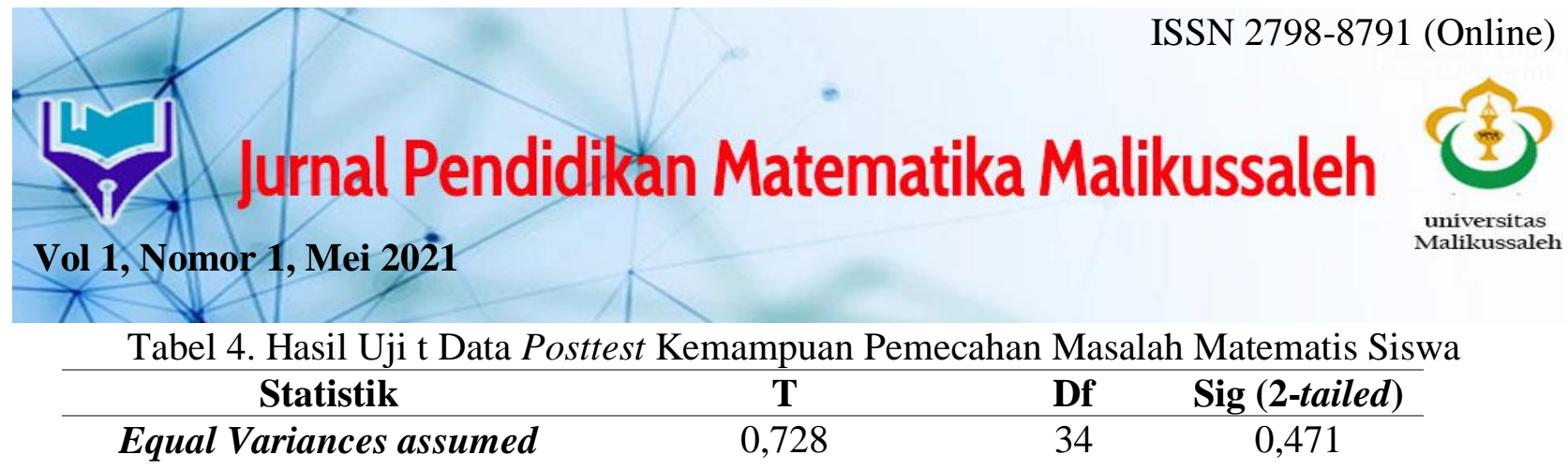

Berdasarkan uji di atas untuk data posttest kemampuan pemecahan masalah matematis siswa didapatkan nilai $0,471>0,05$. Hal ini menunjukkan bahwa $H_{o}$ diterima, artinya tidak terdapat pengaruh kemampuan pemecahan masalah matematis siswa yang diajarkan dengan model Think Pair Share (TPS) dengan kemampuan pemecahan masalah yang diajarkan dengan pembelajaran scientific.

Tabel 5. Uji Normalitas Data Skor $N$-Gain

\begin{tabular}{ccccc}
\hline \multirow{2}{*}{ Kelas } & \multicolumn{3}{c}{ Kolmogorov-Smirnov $^{\boldsymbol{a}}$} & \multirow{2}{*}{ Kesimpulan } \\
\cline { 2 - 4 } & Statistic & Df & Sig & \\
\hline Eksperimen & 0,120 & 19 & 0,200 & $H_{o}$ diterima \\
\hline Kontrol & 0,174 & 17 & 0,183 & \\
\hline
\end{tabular}

Hasil uji normalitas skor $\mathrm{N}$-Gain kemampuan pemecahan masalah matematis siswa yang dihitung menggunakan uji Kolmogorov-Smirnov terlihat bahwa skor $N$-Gain kemampuan pemecahan masalah matematis siswa di kelas eksperimen dan kelas kontrol memiliki nilai sig $>\alpha=0,05$ dikatakan $H_{o}$ diterima. Hasil uji normalitas skor $N$-Gain kemampuan pemecahan masalah matematis siswa pada kelas eksperimen dan kelas kontrol dikatakan berdistribusi normal.

Tabel 6. Hasil Uji Homogenitas Data Skor N-Gain

\begin{tabular}{lllll}
\hline Based On Mean & Levene Statistic & df1 & df2 & Sig \\
\cline { 2 - 5 } & 0,029 & 1 & 34 & 0,865 \\
\hline
\end{tabular}

Hasil uji homogenitas data $N$-Gain kemampuan pemecahan masalah matematis siswa pada kelas eksperimen dan kelas kontrol adalah 0,865 dinyatakan bahwa nilai $p$ value (sig) $\geq$ 0,05 yang dapat dilihat di bab 4, dan dikatakan bahwa uji homogenitas data $N$-Gainkemampuan pemecahan masalah matematis siswa pada kelas eksperimen dan kelas kontrol adalah homogen.

Tabel 7. Hasil Uji t Data N-Gain Kemampuan Pemecahan Masalah Matematis Siswa

\begin{tabular}{cccc}
\hline Statistik & T & Df & Sig (2-tailed) \\
\hline Equal Variances assumed & 1.239 & 34 & 0,224
\end{tabular}

Berdasarkan uji di atas, didapatkan nilai 0,224 >0,05. Hal ini menunjukkan bahwa $H_{o}$ diterima, artinya kemampuan pemecahan masalah matematis siswa yang diajarkan dengan model Think Pair Share (TPS) sama secara signifkan dengan kemampuan pemecahan masalah yang diajarkan dengan pembelajaran scientific.

Hasil analisis data penelitian ini menunjukkan bahwa peningkatan kemampuan pemecahan masalah matematis siswa menggunakan model Think Pair Share (TPS) terlampau hampir sama dengan peningkatan kemampuan pemecahan masalah matematis siswa yang 


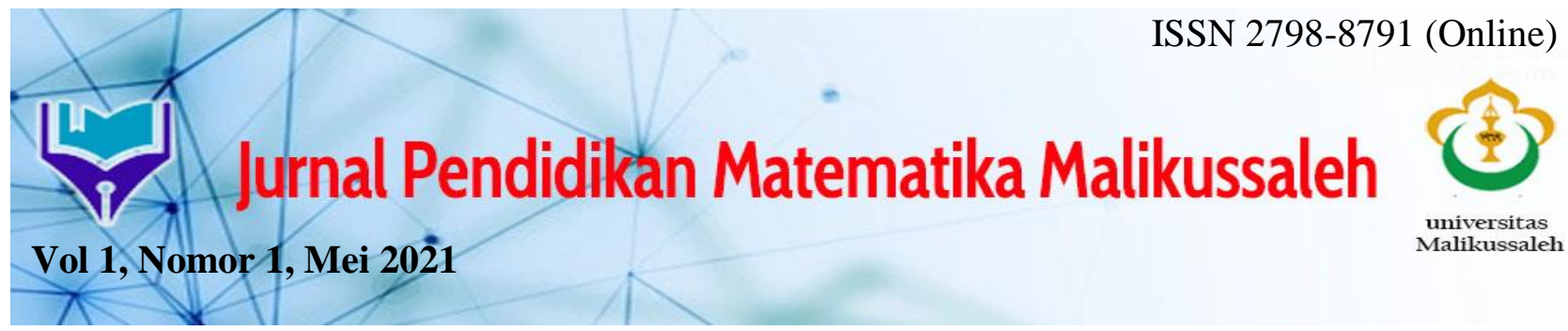

menggunakan pembelajaran scientific. Hal ini bisa dilihat dari rata - rata skor $N$-Gain pada kelas eksperimen dan kelas kontrol. Hal tersebut dapat disimpulkan bahwa kemampuan pemecahan masalah matematis siswa yang diajarkan menggunakan model Think Pair Share (TPS) secara signifikan sama dengan kemampuan pemecahan masalah matematis siswa yang diajarkan menggunakan pembelajaran scientific pada materi pertumbuhan, peluruhan, bunga dan anuitas kelas X SMK Negeri 7 Lhokseumawe. Hasil pembelajaran yang menggunakan model Think Pair Share (TPS) dengan pembelajaran scientific didapatkan sama nilainya secara signifikan, karena dapat dikatakan pembelajaran yang biasa di terapkan disekolah tersebut sudah sangat baik, maka tidak ada terdapat perbedaan yang cukup signifikan antara pembelajaran Think Pair Share (TPS) dengan pembelajaran scientific.

Alasan utama kenapa bisa dikatakan penelitian yang dilakukan dengan model Think Pair Share (TPS) sama hasil uji hipotesisnya dengan pembelajaran scientific, karena pada saat penelitian yang dilakukan pada kelas eksperimen berlangsung siswa yang dikelompokkan menjadi 2 orang dalam satu grup membuat siswa kurang mampu berorganisasi ataupun saling berdiskusi dengan baik dalam grup saat pembelajaran berlangsung dan juga didalam kelompok yang hanya berisikan 2 orang dalam grup membuat kurangnya ide-ide yang muncul sehingga membuat siswa dalam grup tersebut kesulitan dalam menyelesaikan masalah yang diberikan oleh guru. Hal ini sejalan dengan penelitian yang dilakukan oleh Qurniati (2020: 36) model pembelajaran NHT sangat sesuai diterapkan disekolah daripada model pembelajaran Think Pair Share (TPS), hal ini disebabkan karena kegiatan pembelajaran siswa menjadi lebih menyenangkan dan lebih mudah terkontrol dibandingkan dengan model TPS. Selain itu, pembelajaran scientific menjadikan siswa lebih aktif dalam mengkontruksikan pengetahuan dan keterampilan dalam memecahkan soal matematis.

\section{KESIMPULAN}

1. Tidak terdapat pengaruh Kemampuan pemecahan masalah matematis siswa yang diajarkan dengan model Think Pair Share (TPS) terhadap kemampuan pemecahan masalah siswa yang diajarkan dengan pembelajaran scientific

2. Peningkatan kemampuan pemecahan masalah matematis siswa yang diajarkan melalui pembelajaran model Think Pair Share (TPS) sama secara signifikan dengan kemampuan pemecahan masalah matematis siswa yang diajarkan dengan pembelajaran scientific.

\section{DAFTAR PUSTAKA}

Aditya, P. T. (2018). Pengembangan Media Pembelajaran Matematika Berbasis Web Pada Materi Lingkaran Bagi Siswa Kelas Viii. Jurnal Matematika Statistika Dan Komputasi, 15(1), 64. https://doi.org/10.20956/jmsk.v15i1.4425

Afriansyah, A. E., \& Ulva, S. (2016). Kemampuan Pemecahan Masalah Matematis Siswa Ditinjau Melalui Model Pembelajaran SAVI dan Konvensional. Jurnal Riset Pendidikan, 2(2), 142-153. 
Fatimah, A. E. (2016). Peningkatan Kemampuan Pemecahan Masalah Matematis dan Kemandirian Belajar Siswa SMK Negeri 1 Percut Sei Tuan Melalui Pendekatan Differentiated Instruction. MES (Journal of Mathematics Education and Science), 2(1), 11-23.

http://ridum.umanizales.edu.co:8080/jspui/bitstream/6789/377/4/Mu?oz_Zapata_Adria na_Patricia_Art?culo_2011.pdf

Handayani, H. (2017). Upaya Meningkatkan Kemampuan Pemecahan Masalah Matematis dan Aktivitas Siswa Melalui Pembelajaran Kooperatif Learning Tipe Jigsaw di Kelas II Sekolah Dasar. Golden Age: Jurnal Pendidikan Anak Usia Dini, 1(1), 39-45. https://doi.org/10.29313/ga.v1i1.2687

Hendri, Sherlyane; Kenedi, A. K. (2018). Pengembangan Perangkat Pembelajaran Matematika Berbasis Discovery Learning Untuk Meningkatkan Kemampuan Pemecahan Masalah Siswa Kelas VIII Smp. JIP, 8(2), 10-24. https://doi.org/10.31980/mosharafa.v6i2.314

Latif, S. (2017). Mathematical Connection Ability in Solving Mathematics Problem Based on Initial Abilities of Students At Smpn 10 Bulukumba. Jurnal Daya Matematis, 4(2), 207. https://doi.org/10.26858/jds.v4i2.2899

Marhami. (2018). Peningkatan Kemampuan Komunikasi Matematis Siswa SMP Melalui Strategi Pembelajaran Konflik Kognitif. Jurnal Numeracy, 5(2), 146-153.

Witaningtyas, D., LASMAWAN, M., \& ADNYANA, M. (2016). Pengaruh Model Pembelajaran Kooperatif Tipe Think Pair Share Terhadap Sikap Ilmiah Dan Hasil Belajar IPA Siswa Kelas V SD No 4 Ungasan Kecamatan Kuta Selatan. Jurnal Pendidikan Dasar Ganesha, 6(1), 125003.

Sani, B., \& Kurniasih, I. (2016). Ragam Pengembangan Model Pembelajaran Untuk Meningkatkan Professional Guru. Jakarta: Kata Pena.

Sugiyono. (2016). Metode Penelitian Kuantitatif, Kualitatif, dan R\&D. Bandung: CV Alvabeta.

Zulfah. (2017). Pengaruh Penerapan Model Pembelajaran Kooperatif Tipe Think Pair Share Dengan Pendekatan Heuristik Terhadap Kemampuan Pemecahan Masalah Matematis Siswa MTs Negeri Naumbai Kecamatan Kampar. Jurnal Cendekia : Jurnal Pendidikan Matematika, 01(2), 1-12. 